\title{
Analisis pengaruh Return On Asset (ROA), Return On Equity (ROE), Earning Per Share (PER), dan Price Earning Ratio (PER) terhadap harga saham yang konsisten listing pada Jakarta Islamic Index (JII)
}

\author{
Muhammad Muhajir Aminy \\ Universitas Islam Negeri Mataram, Indonesia \\ Corresponding e-mail: azeer.elkhawarizm@uinmataram.ac.id
}

\begin{abstract}
submitted: $\quad$ Purpose - This paper discusses the influence of the company's financial Aug-29, 2019 ratios, namely Return On Assets (ROA), Return on Equity (ROE), Earning Per Share (EPS), and Price Earning Ratio (PER) on stock price movements listed on accepted: Jakarta Islamic Index (JII).

Oct-02, 2019 Research method - This study uses a quantitative approach with panel data published: $\quad$ regression analysis method with eight companies as samples.

Dec-02, 2019 Result - This study found that all variables affect the movement of stock prices since in a simultaneous test with the value of Prob. $F<$ alpha $(0,05)$ and adjusted R-Squared value is 0,9709. While in partial test, EPS and PER are the only variables that have an impact on stock price movements. The variable that has a dominant influence on stock prices is EPS with a regression coefficient of 1,206877 .
\end{abstract}

Keywords: EPS, Jakarta Islamic index, PER, ROA, ROE, stock price

Journal of Enterprise and Development (JED) is licensed under a Creative Commons AttributionShareAlike 4.0 International License. 


\section{PENDAHULUAN}

Jual beli saham adalah salah satu aktivitas keuangan yang telah dihalalkan dengan beberapa ketentuan yang ditetapkan oleh Dewan Syariah Nasional Majelis Ulama Indonesia (DSN-MUI). Hal ini tercantum pada Fatwa DSN-MUI No. 80 yang mengatur mekanisme perdagangan saham agar sesuai dengan syariah Islam. Dengan adanya fatwa ini, umat muslim yang ingin melakukan aktivitas perdagangannya pada pasar modal akan merasa nyaman dan tidak merasa ragu dengan kehalalan kegiatan jual beli saham. Hal ini tentu memicu pertumbuhan aktivitas jual beli saham pada pasar modal di Indonesia dengan mayoritas masyarakatnya beragama Islam.

Dalam kegiatan investasi pada saham, sudah sepatutnya investor melakukan analisis untuk mengambil keputusan menjual ataukah membeli saham suatu perusahaan. Analisis tersebut adalah analisis teknikal dan analisis fundamental saham. Menurut Husnan (2001) analisis teknikal adalah upaya untuk memperkirakan harga saham (kondisi pasar) dengan mengamati perubahan harga saham tersebut di waktu yang lalu. Pemikiran yang mendasari analisis teknikal adalah bahwa harga saham mencerminkan informasi yang relevan. Informasi tersebut ditunjukkan oleh perubahan harga di waktu yang lalu, dan karenanya perubahan harga saham akan mempunyai pola tertentu dan pola tersebut akan berulang. Harga saham yang tinggi mengindikasikan saham tersebut aktif diperdagangkan. Apabila suatu saham aktif diperdagangkan, maka dealer tidak akan lama menyimpan saham tersebut sebelum diperdagangkan. Hal ini akan mengakibatkan menurunnya biaya kepemilikan, dan pada akhirnya menurunkan nilai bid ask spread.

Sementara menurutnya lagi, analisis fundamental adalah analisis yang mencoba memperkirakan harga saham di masa yang akan datang dengan mengestimasi nilai faktor-faktor fundamental, dan menerapkan hubungan antarvariabel tersebut sehingga diperoleh taksiran harga saham yang akan datang.

Menurut Kamaruddin (2004) perbedaan investor yang menggunakan analisis fundamental dan teknikal dalam berinvestasi pada pasar modal salah satunya adalah karakteristik investor itu sendiri. Investor yang menggunakan analisis fundamental adalah investor yang memiliki tujuan menabung dan investasi dalam jangka menengah dan panjang, sementara investor yang menggunakan analisis teknikal memiliki tujuan untuk melakukan perdagangan saham dalam jangka pendek.

Rasio keuangan yang diperoleh dari laporan keuangan merupakan variabel fundamental yang ada pada perusahaan. Dalam berinvestasi investor melihat dua komponen utama dalam laporan keuangan, yaitu Earning Per Share (EPS) dan Price Earning Ratio (PER). Menurut Tandelilin (2001), ada tiga alasan mengapa dua komponen tersebut perlu diperhatikan oleh investor guna membantu keputusan berinvestasi, diantaranya adalah :

1. Pada dasarnya dua komponen tersebut mampu mengestimasi nilai intrinsik saham 
Analisis pengaruh Return On Asset (ROA), Return On Equity (ROE), Earning... Journal of Enterprise and Development (JED), Vol. 1, No. 2, December 2019

2. Deviden yang dibayarkan oleh perusahaan-perusahaan pada dasarnya berasal dari earning

3. Adanya hubungan antara perubahan earning dengan perubahan harga saham

Indikator Return On Asset (ROA) dan Return On Equity (ROE) juga perlu diperhatikan oleh investor untuk mengetahui sejauh mana investasi yang akan dilakukan oleh investor mampu memberikan return yang sesuai dengan tingkat yang disyaratkan oleh investor (Tandelilin, 2001).

Laporan keuangan yang memuat rasio keuangan perusahaan tersebut sangat bermanfaat bagi para investor, karena dengan menganalisa rasio keuangan yang telah disebutkan (EPS, PER, ROA, dan ROE) mereka dapat dengan mudah menentukan keputusan terbaik untuk membeli atau menjual saham suatu perusahaan emiten yang ada dan mampu menghasilkan keuntungan.

Sebelumnya telah ada beberapa penelitian yang sama dengan penelitian ini walaupun dengan variabel maupun objek yang berbeda. Penelitian yang dilakukan oleh Khusna (2009) dengan judul "Analisis Pengaruh Variabel Fundamental Terhadap Harga Saham Perusahaan Pertambangan (Studi Pada Bursa Efek Indonesia)". Hasil dari penelitian ini menyimpulkan bahwa variabelvariabel fundamental yang diteliti (ROA, ROE, EPS, DPR, dan PER) apabila diuji secara simultan akan berpengaruh secara signifikan terhadap pergerakan harga saham perusahaan yang telah listing pada Bursa Efek Indonesia. Namun ketika variabel-variabel ini diuji secara parsial diketahui bahwa hanya variabel EPS yang memiliki pengaruh yang signifikan terhadap harga saham, sementara variabel lainnya tidak memiliki pengaruh terhadap pergerakan harga saham.

Penelitian Deitiana (2011) dengan judul "Pengaruh Rasio Keuangan, Pertumbuhan Penjualan, dan Deviden Terhadap Harga Saham" menemukan bahwa secara parsial hanya variabel profitabilitas dengan angka signifikansi 0,001 (lebih kecil dari alpha 0,05) yang memiliki pengaruh secara signifikan terhadap pergerakan harga saham, sementara variabel likuiditas, deviden, dan pertumbuhan penjualan tidak berpengaruh terhadap pergerakan harga saham. Secara simultan, besar pengaruh seluruh variabel yang diteliti sebesar 11,3\%. Hal ini dijelaskan dengan nilai Adjusted R-Square yang menunjukkan nilai 0,113 pada hasil penelitian. $88,7 \%$ sisanya dijelaskan oleh faktor-faktor lainnya yang tidak dijelaskan dalam penelitian.

Penelitian Permana dan Sularto (2008) yang berjudul "Analisis Pengaruh Fundamental Keuangan, Tingkat Bunga SBI, dan Tingkat Inflasi Terhadap Pergerakan Harga Saham" menemukan bahwa seluruh variabel independen yang diteliti (pendapatan per saham, rasio pendapatan harga, nilai buku saham, nilai buku harga, pengembalian ekuitas, tingkat bunga SBI, dan tingkat inflasi) secara simultan berpengaruh terhadap pergerakan harga saham dalam penelitian. Sementara secara parsial hanya variabel nilai buku harga dengan signifikansi 0,001 (lebih kecil dari alpha 0,05) yang memiliki pengaruh secara signifikan terhadap pergerakan harga saham. 
Penelitian yang dilakukan Sussanto dan Nurliana (2009) dengan judul "Analisis Pengaruh Fundamental dan Risiko Sistemik Terhadap Harga Saham Pada Perusahaan Perdagangan di BEI" menemukan bahwa secara parsial, hanya nilai buku yang mempengaruhi pergerakan harga saham. Sementara secara simultan, semua rasio fundamental (ROA, ROE, rasio pembagian deviden, rasio hutang terhadap ekuitas, nilai buku, laju pengembalian yang diinginkan) dan risiko sistemik berpengaruh terhadap pergerakan harga saham.

Penelitian Widyatmini dan Damanik (2009) yang berjudul "Pengaruh Pertambahan Nilai Ekonomis dan Analisis Fundamental Terhadap Harga Saham (Studi Pada Sektor Industri Perdagangan Retail)" menemukan bahwa pertambahan nilai ekonomis tidak memiliki pengaruh terhadap harga saham, sehingga kurang tepat untuk digunakan dalam memprediksi harga saham. Rasionalitas fundamental lainnya, seperti : current ratio, quick ratio, asset turnover ratio, inventory turnover ratio, gross profit margin ratio, return on asset ratio, return on equity ratio, debt ratio, debt equity ratio, leverage ratio, dan price earning ratio tidak memiliki pengaruh terhadap harga saham. Sementara apabila seluruh rasio dalam analisis fundamental dan pertambahan nilai ekonomis diuji secara simultan akan berpengaruh terhadap harga saham.

Penelitian Nugroho (2009) dengan judul "Analisis Pengaruh Pengembalian Investasi dan Penerimaan Per Saham Terhadap Harga Saham (Studi Pada Perusahaan Rokok di Bursa Efek Indonesia)" menyimpulkan bahwa secara simultan variabel pengembalian investasi dan penerimaan per saham memiliki pengaruh signifikan terhadap harga saham perusahaan rokok yang ada di Bursa Efek Indonesia. Hal ini terlihat pada angka signifikansi pengujian sebesar 0,002 yang lebih kecil dari alpha, yaitu 0,05. Pengujian secara parsial menjelaskan bahwa variabel laju pengembalian investasi dan penerimaan per saham tidak memperlihatkan pengaruh yang signifikan terhadap harga saham. Nilai signifikansi pada pengembalian investasi sebesar 0,903 (lebih besar dari alpha $0,05)$. Begitu juga dengan nilai signifikan variabel penerimaan per saham memperlihatkan angka 0,099 yang lebih besar dari alpha 0,05.

Penelitian yang telah dilakukan Haryanto dan Sugiharto (2003) berjudul "Pengaruh Rasio Profitabilitas Terhadap Harga Saham Pada Perusahaan Industri Minuman di Bursa Efek Jakarta" menjelaskan bahwa dari beberapa rasio profitabilitas yang diteliti, hanya ROE yang memiliki pengaruh secara signifikan terhadap pergerakan harga saham dengan hubungan yang kuat dan searah. ROA tidak berpengaruh terhadap harga saham, namun memiliki korelasi positif. Profit Margin tidak berpengaruh terhadap harga saham, namun memiliki korelasi positif. Sementara apabila dilakukan pengujian secara simultan, ROA, ROE, dan Profit Margin memiliki pengaruh yang signifikan terhadap harga saham sebagai variabel dependen dalam penelitian.

Penelitian Hadianto dan Setiawan (2007) yang berjudul "Pengaruh Volume Perdagangan, EPS, dan PER Terhadap Harga Saham Sektor Pertambangan Pada Periode 2000 - 2005 di Bursa Efek Jakarta" menemukan bahwa volume perdagangan, laba bersih per saham (EPS), dan rasio harga terhadap laba (PER) 
Analisis pengaruh Return On Asset (ROA), Return On Equity (ROE), Earning... Journal of Enterprise and Development (JED), Vol. 1, No. 2, December 2019

secara parsial berpengaruh positif dan signifikan terhadap harga saham. Berdasarkan analisis terhadap sampel saham sektor pertambangan pada periode penelitian, seluruh variabel independen (volume perdagangan, laba bersih, PER, dan PER) berpengaruh secara simultan terhadap harga saham.

Penelitian Pasaribu (2008) dengan judul "Pengaruh Variabel Fundamental Terhadap Harga Saham Perusahaan Go Public di BEI” menemukan bahwa baik secara simultan maupun parsial, pertumbuhan, profitabilitas, posisi leverage, likuiditas, dan efisiensi perusahaan berpengaruh signifikan terhadap harga saham di delapan industri yang menjadi objek penelitian. Secara simultan, seluruh variabel independen tersebut mampu menjelaskan variansi harga saham sebesar $85,41 \%$ pada industri barang konsumsi, $77,83 \%$ pada aneka industri., dan $46,32 \%$ pada enam industri lainnya. Variabel EPS merupakan variabel yang memiliki pengaruh dominan pada enam industri, sedangkan profitabilitas hanya dominan pada industri pertanian. Likuiditas berpengaruh dominan pada industri properti dan real estate.

Terakhir adalah penelitian yang dilakukan oleh Zuliarni (2012) yang berjudul "Pengaruh Kinerja Keuangan Terhadap Harga Saham Pada Perusahaan Mining And Mining Service Di Bursa Efek Indonesia (BEI)" menemukan bahwa terdapat pengaruh yang signifikan antara ROA dan harga saham. Hal ini mengindikasikan bahwa perusahaan mining and mining service telah berhasil memanfaatkan dan memaksimalkan laba bersih berdasarkan tingka aset tertentu yang menjadi acuan penting bagi investor dalam membuat keputusan investasi. Selain itu, penulis juga menemukan bahwa PER memiliki pengaruh yang signifikan terhadap harga saham, sementara DPR tidak memiliki pengaruh terhadap harga saham.

\section{KAJIAN LITERATUR}

\section{Saham Syariah Dan Kriteria Emitennya}

Menurut Fatwa DSN-MUI No. 40/DSN-MUI/X/2003, saham syariah adalah bukti kepemilikan atas suatu perusahaan yang memenuhi kriteria sebagaimana tercantum dalam kriteria berikut, dan tidak termasuk dalam saham yang memiliki hak-hak istimewa.

Diantara kriteria-kriteria perusahaan emiten penerbit saham syariah tersebut antara lain :

1. Tidak adanya pertentangan terhadap syariat Islam pada jenis usaha, produk yang dihasilkan, serta akad dan cara pengelolaan perusahaan emiten penerbit saham syariah

2. Diantara kegiatan yang bertentangan dengan syariat Islam adalah :

a. Perjudian dan segala bentuk permainan yang tergolong judi atau perdagangan yang dilarang 
b. Lembaga keuangan konvensional, termasuk perbankan dan asuransi konvensional

c. Produsen, distributor, atau pedagang makanan dan minuman yang haram

d. Produsen, distributor, dan atau penyedia barang-barang yang merusak moral dan bersifat mudharat

e. Melakukan investasi pada emiten yang pada saat transaksi tingkat (nisbah) hutang perusahaan kepada lembaga keuangan ribawi lebih dominan ketimbang modalnya

3. Emiten atau Perusahaan Publik yang bermaksud menerbitkan efek syariah wajib menandatangani dan memenuhi ketentuan akad yang sesuai dengan syariah atas efek syariah yang dikeluarkan

4. Emiten atau Perusahaan Publik yang menerbitkan efek syariah wajib menjamin bahwa kegiatan usahanya memenuhi prinsip-prinsip syariah dan memiliki Shariah Compliance Officer

5. Apabila Emiten atau Perusahaan Publik yang menerbitkan efek syariah tersebut sewaktu-waktu tidak memenuhi persyaratan tersebut diatas, maka efek yang diterbitkan dengan sendirinya tidak termasuk dalam efek syariah

\section{Harga Saham Dan Faktor Penggeraknya}

Menurut Jogiyanto (2000), pengertian harga saham adalah "harga saham yang terjadi di pasar bursa pada saat tertentu yang ditentukan oleh pelaku pasar dan ditentukan oleh permintaan dan penawaran saham yang bersangkutan di pasar modal".

Harga saham terbagi atas tiga jenis (Anoraga dan Pakarti, 2006), yaitu :

a. Par Value (Nilai Nominal), merupakan nilai yang tercantum pada saham

b. Base Price (Harga Dasar), merupakan harga perdana untuk menentukan nilai dasar

c. Market Price (Harga Pasar), merupakan harga pada pasar riil dan merupakan harga yang paling mudah ditentukan karena harga ini adalah harga dari suatu saham yang sedang berlangsung atau jika pasar sudah tutup maka harga pasar saat itu adalah harga penutupannya (closing price)

Di bursa saham dikenal beberapa istilah terkait dengan harga saham (Hin, 2008), yaitu :

a. Open (pembukaan) : harga yang terjadi pada transaksi pertama satu saham

b. High (tertinggi) : harga tertinggi transaksi yang tercapai pada satu saham

c. Low (terendah) : harga terendah transaksi yang tercapai pada satu saham

d. Close (penutupan) : harga yang terjadi pada transaksi terakhir satu saham

e. Bid (minat beli) : harga yang diminati pembeli untuk melakukan transaksi 
Analisis pengaruh Return On Asset (ROA), Return On Equity (ROE), Earning... Journal of Enterprise and Development (JED), Vol. 1, No. 2, December 2019

f. Ask (minat jual) : harga yang diminati penjual untuk melakukan transaksi

Harga saham terbentuk di pasar modal dan ditentukan oleh beberapa faktor, diantaranya adalah Earning Per Share (EPS), Price Earning Ratio (PER), tingkat bunga bebas resiko yang diukur dari tingkat bunga deposito pemerintah, dan tingkat kepastian operasi perusahaan (Sartono, 2001).

Banyak orang berasumsi bahwa chart harga saham yang terbentuk pada bursa saham memiliki pola yang sama dan akan terus berulang. Oleh karenanya, mereka mengatakan bahwa harga yang akan datang dapat diprediksikan dengan melihat pola chart harga saham yang terbentuk pada pasar bursa. Hal ini sebagaimana dikatakan oleh Fama (1965) bahwa "...they all assume that the past behavior of a security's price is rich in information concerning in its future behavior. History repeats itself in that patterns of past price behavior will tend to recur in the future".

Ada beberapa faktor yang menyebabkan tingkat volatilitas harga saham yang diperdagangkan pasar modal semakin tinggi. Salah satu faktor yang paling mempengaruhi volatilitas harga saham tersebut adalah faktor fundamental, dimana faktor tersebut berkaitan langsung dengan perusahaan emiten penerbit saham (Arifin, 2004). Kinerja perusahaan emiten penerbit saham ini berbanding lurus dengan harga sahamnya, dimana ketika kinerja perusahaan semakin baik maka harga saham juga akan semakin tinggi. Begitu pula sebaliknya, semakin buruk kinerja perusahaan maka semakin rendah pula harga sahamnya. Faktorfaktor fundamental ini dapat dilihat dari kondisi keuangan perusahaan emiten, strategi bisnisnya, produk yang dihasilkan, manajemen perusahaan, dan lainnya yang berkaitan dengan kinerja perusahaan.

Menurut Sitompul (2004), dalam analisis fundamental harga saham perusahaan dipengaruhi oleh beberapa unsur, yaitu :

a. Kebijakan deviden perusahaan

b. Nilai buku dari aset dan bisnis perusahaan

c. Cash Flow

d. Tingkat laba yang dicapai oleh perusahaan

\section{METODE PENELITIAN}

\section{Jenis Data}

Data yang digunakan dalam penelitian ini adalah data sekunder yang diambil dari laporan keuangan tahunan (annual report) perusahaan-perusahaan yang konsisten listing pada Jakarta Islamic Index (JII) pada periode 2008 - 2012. Perusahaan yang akan diteliti dalam penelitian ini adalah :

a. PT Astra Agro Lestari

b. PT Indocement Tunggal Prakarsa

c. PT Kalbe Farma 
d. PT Unilever Indonesia

e. PT United Tractors

f. PT Aneka Tambang

g. PT Telekomunikasi Indonesia

h. PT Tambang Batubara Bukit Asam

\section{Definisi Operasional Variabel}

Diantara variabel-variabel yang digunakan dalam penelitian ini adalah :

a. Return On Asset (ROA)

Mengukur kemampuan perusahaan menghasilkan laba bersih berdasarkan tingkat aset tertentu

$$
\text { ROA = (Laba Bersih) } /(\text { Total Aset })
$$

b. Return On Equity (ROE)

Mengukur kemampuan perusahaan menghasilkan laba bersih berdasarkan modalnya

$$
\text { ROE = (Laba Bersih }) /(\text { Total Modal })
$$

c. Earning Per Share (EPS)

Menggambarkan jumlah laba bersih setelah pajak pada satu tahun buku yang dihasilkan setiap lembar saham

$$
\text { EPS = (Laba Bersih }) /(J u m l a h \text { Saham Beredar })
$$

d. Price Earning Ratio (PER)

Melihat harga saham relatif terhadap earning-nya. Bagi investor, semakin kecil PER suatu saham, semakin bagus karena saham tersebut termasuk saham dengan harga murah

$$
\text { PER = (Harga Saham Per Lembar }) / E P S
$$


Analisis pengaruh Return On Asset (ROA), Return On Equity (ROE), Earning... Journal of Enterprise and Development (JED), Vol. 1, No. 2, December 2019

\section{e. Harga Saham}

Harga jual saham pada suatu bursa efek. Harga saham yang digunakan adalah harga penutupan (closing price) pada periode tertentu

\section{Teknik Pengolahan Data}

Teknik pengolahan data yang digunakan oleh peneliti adalah analisis regresi data panel dengan bantuan aplikasi Microsoft Excel 2010 dan StataSE 12.0. Hal ini dikarenakan data yang digunakan oleh peneliti memiliki sifat time series dan cross section. Menurut Gujarati (2011) data panel adalah kombinasi dari data time series dan cross section, dimana dengan mengakomodasi informasi yang baik yang berkaitan dengan variabel-variabel time series dan cross section, data panel secara substansial mampu menurunkan masalah omitted-variables, yaitu model yang mengabaikan variabel yang relevan.

Keunggulan metode regresi data panel diantaranya adalah :

1. Dengan adanya data yang bersifat time series dan cross-section membuat analisis regresi data panel menjadi lebih informatif, lebih variatif, memiliki derajat kebebasan (degree of freedom) yang lebih tinggi, dan meminimalisir terjadinya korelasi antarvariabel

2. Data panel berhubungan dengan individu, perusahaan, negara, dan lainnya selama beberapa waktu dengan batasan heterogenitas di setiap unitnya

3. Analisis data panel adalah analisis yang lebih sesuai untuk mempelajari perubahan yang dinamis

4. Data panel dapat meminimalkan bias yang mungkin terjadi ketika membahasnya dalam bentuk agregat

5. Data panel dapat digunakan untuk mempelajari model-model perilaku

Ajija et al (2011) mengemukakan bahwa kelebihan-kelebihan yang ada di atas memiliki implikasi tidak diharuskannya pengujian asumsi klasik pada model data panel, karena penelitian yang menggunakan data panel memperbolehkan identifikasi parameter tertentu tanpa perlu membuat asumsi yang ketat atau tidak mengharuskan terpenuhinya semua asumsi klasik regresi linier seperti pada ordinary least square (OLS).

Sesuai dengan pengertian analisis regresi data panel yang memiliki sifat time series dan cross-section, maka analisis regresi data panel ini merupakan model gabungan antara dua sifat tersebut. Dengan mengadopsi model umum analisis regresi data panel yang dijelaskan oleh Nachrowi dan Usman (2006), maka peneliti mengajukan model untuk penelitian ini sebagai berikut :

$$
\operatorname{LnHS}_{i t}=\alpha+\beta \mathrm{ROA}_{i t}+\beta R O E_{i t}+\beta \operatorname{LnEPS} S_{i t}+\beta P E R_{i t}+\varepsilon_{i t}
$$


Dimana :

$\begin{array}{ll}\mathrm{i} & =1,2, \ldots, \mathrm{N} \text { (data cross-section) } \\ \mathrm{t} & =1,2, \ldots, \mathrm{T} \text { (data time series) } \\ \mathrm{LnHS} & =\text { Ln Harga Saham } \\ \alpha & =\text { intercept (konstanta regresi) } \\ \beta & =\text { slope (kemiringan garis regresi) } \\ \mathrm{ROA} & =\text { Return On Asset } \\ \mathrm{ROE} & =\text { Return On Equity } \\ \text { LnEPS } & =\text { Ln Earning Per Share } \\ \mathrm{PER} & =\text { Price Earning Ratio } \\ \varepsilon & =\text { error term }\end{array}$

\section{HASIL DAN PEMBAHASAN}

\section{Analisis Model Data}

\section{Chow Test}

Chow Test adalah salah satu teknik pengujian dalam analisis data panel untuk membandingkan model data yang sesuai digunakan antara Pooled Least Square (PLS) dan Fixed Effect Model (FEM). Metode yang dipakai dalam membandingkan dua model tersebut adalah dengan cara melihat nilai Prob F yang tertera pada baris terakhir hasil olah data metode Fixed Effect Model (FEM). Berikut hasil olah data model tersebut :

Tabel 1. Hasil Pengolahan Menggunakan Fixed Effect Model (FEM)

\begin{tabular}{|l|l|l|}
\hline R-Square & within & 0.8542 \\
\hline & between & 0.9817 \\
\hline & overall & 0.9645 \\
\hline Coefficient & roa & 0.021642 \\
\hline & roe & -0.008478 \\
\hline & lneps & 1.115092 \\
\hline & per & 0.079337 \\
\hline & constanta & 0.411875 \\
\hline Corr $\left(\mathrm{u}_{-} \mathrm{i}, \mathrm{Xb}\right)$ & & 0.1037 \\
\hline F $(7,28)$ & & 1.31 \\
\hline Prob $>$ F & & 0.2833 \\
\hline
\end{tabular}


Analisis pengaruh Return On Asset (ROA), Return On Equity (ROE), Earning... Journal of Enterprise and Development (JED), Vol. 1, No. 2, December 2019

Hipotesis yang digunakan dalam menentukan model data adalah sebagai berikut :

HO : PLS

H1 :FEM

Kriteria Penilaian $\quad$ : Tolak H0 apabila output Prob. F baris terakhir $<0,05$

Berdasarkan kriteria tersebut, maka dapat disimpulkan bahwa model yang digunakan pada penelitian ini adalah Pooled Least Square (PLS). Output Prob. F yang dihasilkan adalah 0,2833 (Prob. F > 0,05), sehingga H0 (PLS) diterima dan H1 (FEM) ditolak.

\section{LM Test}

LM Test atau lengkapnya The Breusch - Pagan LM Test digunakan sebagai pertimbangan statistik dalam memilih antara Pooled Least Square (PLS) dengan Random Effect Model (REM). Metode yang dipakai dalam membandingkan dua model tersebut adalah dengan cara melihat nilai Prob Chibar2 yang tertera pada hasil olah data LM Test. Berikut hasilnya :

Tabel 2. Hasil Pengujian LM Test

\begin{tabular}{|c|c|c|}
\hline \multicolumn{3}{|c|}{ Estimated results } \\
\hline & Var & $\begin{array}{l}\text { sd = sqrt } \\
(\text { Var) }\end{array}$ \\
\hline lnhargasaham & 1.999193 & 1.413928 \\
\hline $\mathrm{e}$ & 0.054856 & 0.2342145 \\
\hline $\mathrm{u}$ & 0.007381 & 0.0859114 \\
\hline Chibar2 (01) & 0.03 & \\
\hline Prob > chibar 2 & 0.4279 & \\
\hline
\end{tabular}

Hipotesis yang digunakan dalam menentukan model data adalah sebagai berikut :

$\mathrm{HO}$

$$
\text { : PLS }
$$

H1

$$
\text { : REM }
$$

Kriteria Penilaian $\quad$ : Tolak H0 apabila Prob. Chibar $<<0,05$

Berdasarkan kriteria tersebut, maka dapat disimpulkan bahwa model yang digunakan pada penelitian ini adalah Pooled Least Square (PLS). Prob. Chibar2 yang dihasilkan adalah 0,4279 (Prob. Chibar2 > 0,05), sehingga H0 (PLS) diterima dan H1 (REM) ditolak. 


\section{Hausman Test}

Hausman Test adalah teknik pengujian yang digunakan untuk memilih model antara Fixed Effect Model (FEM) dengan Random Effect Model (REM). Metode yang dipakai dalam membandingkan kedua model tersebut adalah dengan cara melihat nilai Prob Chi2 yang tertera pada hasil olah data Hausman Test. Berikut hasilnya :

Tabel 3. Hasil Pengujian Hausman Test

\begin{tabular}{|l|l|l|}
\hline & Difference & $\begin{array}{l}\text { sqrt (diag(V_b- } \\
\text { V_B })\end{array}$ \\
\hline roa & 0.0152228 & 0.0098305 \\
\hline roe & -0.0011022 & 0.0045882 \\
\hline lneps & -0.0840783 & 0.1239654 \\
\hline per & -0.0006031 & 0.0039977 \\
\hline & & \\
\hline chi2 (4) & 3.07 & \\
\hline $\begin{array}{l}\text { Prob }> \\
\text { chi2 }\end{array}$ & 0.5455 &
\end{tabular}

Hipotesis yang digunakan dalam menentukan model data adalah sebagai berikut :

HO : REM

H1 :FEM

Kriteria Penilaian : Tolak H0 apabila Prob. Chi2 <0,05

Berdasarkan kriteria tersebut, maka dapat disimpulkan bahwa model yang digunakan pada penelitian ini adalah Random Effect Model (REM). Prob. Chi2 yang dihasilkan adalah 0,5455 (Prob. Chi2 > 0,05), sehingga H0 (REM) diterima dan H1 (FEM) ditolak.

Secara ringkas keputusan penggunaan model data terbaik berdasarkan parameter masing-masing uji dapat disajikan dalam tabel berikut ini :

Tabel 4. Ringkasan Seluruh Hasil Uji Pemilihan Model

\begin{tabular}{|l|l|l|l|}
\hline Jenis Uji & Parameter & Nilai & Keputusan \\
\hline Chow & Prob. F & 0.2833 & PLS \\
\hline LM & Prob.Chibar2 & 0.4279 & PLS \\
\hline Hausman & Prob. Chi2 & 0.5455 & REM \\
\hline
\end{tabular}


Analisis pengaruh Return On Asset (ROA), Return On Equity (ROE), Earning... Journal of Enterprise and Development (JED), Vol. 1, No. 2, December 2019

Berdasarkan seluruh hasil uji tersebut dapat disimpulkan bahwa model yang cocok digunakan dalam penelitian ini adalah model Pooled Least Square (PLS).

\section{Interpretasi Model Data}

Setelah melakukan tiga metode pengujian, peneliti menyimpulkan bahwa model yang sesuai digunakan adalah model Pooled Least Square (PLS). Berikut hasil olah data menggunakan model tersebut :

Tabel 5. Hasil Pengolahan Menggunakan Pooled Least Square (PLS)

\begin{tabular}{|l|l|l|}
\hline & Coefficients & $\mathrm{P}>\mathrm{t}$ \\
\hline roa & 0.0029546 & 0.729 \\
\hline roe & -0.006506 & 0.062 \\
\hline lneps & 1.206877 & 0.0000 \\
\hline per & 0.0804362 & 0.0000 \\
\hline constanta & 0.1401164 & 0.582 \\
\hline & & \\
\hline R-squared & 0.9739 & \\
\hline Adj R-squared & 0.9709 & \\
\hline F (4, 35) & 325.99 \\
\hline Prob > F & 0.0000 \\
\hline Root MSE & 0.24131 \\
\hline
\end{tabular}

Model diatas menghasilkan Prob. F < alpha (0,05), yaitu 0,000 yang mengindikasikan bahwa seluruh variabel independen yang diteliti (ROA, ROE, EPS, dan PER) memiliki pengaruh yang signifikan terhadap pergerakan harga saham sebagai variabel dependen. Nilai adjusted R-Squared 0,9709 menunjukkan bahwa 97,09\% variabel independennya mampu menggambarkan variasi dari harga saham, sementara sisanya yaitu 2,91\% dipengaruhi oleh faktor lainnya yang tidak ada dalam penelitian ini. Nilai konstanta regresi 0,1401164 dapat diinterpretasikan sebagai nilai dari harga saham dengan asumsi nilai semua variabel independen adalah nol.

\section{Pengujian Hipotesis}

\section{Hipotesis Pertama: Return On Asset (ROA)}

H0 : ROA tidak berpengaruh signifikan terhadap harga saham

H1 : ROA berpengaruh signifikan terhadap harga saham 
Hasil uji-t atau uji parsial dapat dilakukan dengan cara melihat nilai Prob.t yang tercantum pada hasil olah data. Nilai Prob. t untuk variabel ROA lebih besar dari alpha $(0,05)$, yaitu 0,729 . Hal ini mengindikasikan bahwa keputusan dari pengujian hipotesis ini adalah tolak $\mathrm{H} 1$ dan terima $\mathrm{H} 0$ yang berarti variabel Return On Asset (ROA) tidak memiliki pengaruh yang signifikan terhadap variasi harga saham. Kesimpulan ini juga ditemukan pada penelitian-penelitian sebelumnya, yaitu penelitian yang dilakukan oleh Haryanto dan Sugiharto (2003), Sussanto dan Nurliana (2009), Widyatmini dan Damanik (2009), dan Khusna (2009).

Kesimpulan ini bertentangan dengan teori yang dikemukakan oleh Tandelilin (2001) yang menyatakan bahwa salah satu indikator yang perlu diperhatikan oleh investor dalam membeli atau menjual saham adalah variabel ROA perusahaan. Khusna (2009) mengatakan bahwa hal ini mungkin terjadi dikarenakan ketidakpercayaan investor terhadap perusahaan untuk menjadikan laba bersih yang diperoleh sebagai aset perusahaan, namun untuk membayar hutangnya.

\section{Hipotesis Kedua: Return On Equity (ROE)}

H0 : ROE tidak berpengaruh signifikan terhadap harga saham

H1 : ROE berpengaruh signifikan terhadap harga saham

Hasil uji-t atau uji parsial dapat dilakukan dengan cara melihat nilai Prob. t yang tercantum pada hasil olah data. Nilai Prob. t untuk variabel ROE lebih besar dari alpha $(0,05)$, yaitu 0,062 . Hal ini mengindikasikan bahwa keputusan dari pengujian hipotesis ini adalah tolak $\mathrm{H} 1$ dan terima $\mathrm{H} 0$ yang berarti variabel Return On Equity (ROE) tidak memiliki pengaruh yang signifikan terhadap variasi harga saham. Kesimpulan yang sama juga ditemukan pada penelitianpenelitian sebelumnya, yaitu penelitian yang dilakukan oleh Sussanto dan Nurliana (2009), Widyatmini dan Damanik (2009), dan Khusna (2009).

Kesimpulan ini bertentangan dengan teori yang dikemukakan oleh Tandelilin (2001) yang menyatakan bahwa salah satu indikator yang perlu diperhatikan oleh investor dalam membeli atau menjual saham adalah variabel ROE perusahaan. Khusna (2009) mengatakan bahwa hal ini mungkin terjadi dikarenakan ketidakpercayaan investor terhadap jaminan atas pengembalian modal yang telah mereka tanam.

\section{Hipotesis Ketiga: Earning Per Share (EPS)}

H0 : EPS tidak berpengaruh signifikan terhadap harga saham

H1 : EPS berpengaruh signifikan terhadap harga saham

Hasil uji-t atau uji parsial dapat dilakukan dengan cara melihat nilai Prob. t yang tercantum pada hasil olah data. Nilai Prob. t untuk variabel EPS lebih kecil dari alpha $(0,05)$, yaitu 0,000 . Hal ini mengindikasikan bahwa keputusan dari 
Analisis pengaruh Return On Asset (ROA), Return On Equity (ROE), Earning... Journal of Enterprise and Development (JED), Vol. 1, No. 2, December 2019

pengujian hipotesis ini adalah tolak $\mathrm{H} 0$ dan terima $\mathrm{H} 1$ yang berarti variabel Earning Per Share (EPS) memiliki pengaruh yang signifikan terhadap variasi harga saham. Kesimpulan yang sama dapat ditemukan pula dalam penelitian yang telah dilakukan oleh Khusna (2009), dan Hadianto dan Setiawan (2007).

Dalam penelitian ini juga ditemukan bahwa variabel EPS memiliki korelasi positif terhadap pergerakan harga saham. Hal ini ditunjukkan oleh koefisien logaritma natural variabel EPS yang tercantum pada hasil olah data menggunakan aplikasi Stata 12.0, yaitu sebesar 1,206877. Artinya, apabila variabel EPS naik sebesar 1 satuan, maka harga saham juga akan mengalami kenaikan sebesar 1,206877 satuan. Koefisien ini juga menjadikan variabel EPS menjadi variabel independen paling berpengaruh untuk menggerakkan harga saham dalam penelitian.

\section{Hipotesis Keempat: Price Earning Ratio (PER)}

HO : PER tidak berpengaruh signifikan terhadap harga saham

H1 : PER berpengaruh signifikan terhadap harga saham

Hasil uji-t atau uji parsial dapat dilakukan dengan cara melihat nilai Prob. t yang tercantum pada hasil olah data. Nilai Prob. t untuk variabel PER lebih kecil dari alpha $(0,05)$, yaitu 0,000 . Hal ini mengindikasikan bahwa keputusan dari pengujian hipotesis ini adalah tolak $\mathrm{H} 0$ dan terima $\mathrm{H} 1$ yang berarti variabel Price Earning Ratio (PER) memiliki pengaruh yang signifikan terhadap variasi harga saham. Penelitian yang dilakukan oleh Hadianto dan Setiawan (2007), dan Zuliarni (2012) menyimpulkan hal yang serupa, yaitu variabel PER memiliki pengaruh yang signifikan terhadap pergerakan harga saham.

Peneliti juga menemukan bahwa variabel EPS memiliki korelasi positif terhadap variasi harga saham. Hal ini ditunjukkan oleh nilai positif dari koefisiennya, yaitu sebesar 0,084362. Interpretasi dari koefisien tersebut adalah apabila PER bergerak 1 satuan, maka harga saham akan mengalami pergerakan yang searah sebesar 0,084362 satuan.

\section{KESIMPULAN}

Berdasarkan hasil analisis data yang telah dilakukan, peneliti dapat menyimpulkan beberapa hal, antara lain :

1. Dalam pengujian simultan, seluruh variabel independen (ROA, ROE, EPS, dan PER) memiliki pengaruh yang signifikan terhadap pergerakan harga saham sebagai variabel dependen. Hal ini dapat dibuktikan dengan nilai Prob. F < alpha $(0,05)$, yaitu 0,0000 . Sementara dalam pengujian parsial, hanya variabel EPS dan PER yang memiliki pengaruh yang signifikan terhadap harga saham. Hal ini dapat dibuktikan dengan nilai Prob. $t<$ alpha $(0,05)$, yaitu 0,0000 pada kedua variabel tersebut. Besar kontribusi pengaruh seluruh variabel 
independen terhadap variabel dependen adalah 97,09\%, sementara sisanya yaitu 2,91\% dipengaruhi oleh faktor-faktor yang tidak ada dalam penelitian.

2. Variabel independen yang memiliki pengaruh paling dominan terhadap harga saham adalah variabel EPS. Hal ini dapat dilihat dari koefisien regresinya yang memiliki nilai tertinggi diantara seluruh variabel independen lainnya, yaitu sebesar 1,208677.

Saran-saran yang dapat diberikan berdasarkan hasil penelitian ini diantaranya adalah :

1. Bagi investor diharapkan agar lebih mempertimbangkan variabel EPS dan PER suatu saham dalam melakukan investasi pada pasar modal syariah. Hal ini dikarenakan kedua variabel tersebut yang memiliki pengaruh yang signifikan terhadap variasi harga saham dalam penelitian, terutama variabel EPS yang merupakan laba per saham dan variabel dengan kontribusi pengaruh terbesar dibandingkan variabel-variabel lainnya. Variabel PER juga perlu diperhatikan karena variabel ini langsung berhubungan dengan EPS atau laba per saham. Selain itu disarankan kepada investor muslim agar tetap memperhatikan nilai-nilai syariah dalam bertransaksi dalam pasar modal seperti tidak melakukan short selling (jual kosong), yaitu menjual sesuatu yang tidak dimiliki dsb. Seorang investor muslim pada pasar modal diharapkan lebih mengedepankan shariah oriented ketimbang profit oriented. Cara paling aman dalam bertransaksi pada pasar modal syariah adalah dengan menggunakan broker yang telah menerapkan jual beli saham dengan prinsip syariah, dan hanya bertransaksi dengan saham-saham perusahaan yang telah listing pada Jakarta Islamic Index (JII) atau Indeks Saham Syariah Indonesia (ISSI).

2. Bagi peneliti selanjutnya diharapkan untuk lebih memperbanyak variabel independennya karena masih banyak variabel-variabel yang memiliki pengaruh terhadap pergerakan harga saham berdasarkan pertimbangan investor di pasar modal, contohnya rasio pembagian deviden (DPR), rasio hutang terhadap ekuitas (DER), dan lainnya.

3. Bagi perusahaan diharapkan lebih memperhatikan kebijakan yang akan dibuat terkait dengan kinerja keuangannya karena dapat mempengaruhi pergerakan harga saham di pasar modal. 
Analisis pengaruh Return On Asset (ROA), Return On Equity (ROE), Earning... Journal of Enterprise and Development (JED), Vol. 1, No. 2, December 2019

\section{DAFTAR PUSTAKA}

Ajija, Shochrul R et al. 2011. Cara Cerdas Menguasai Eviews. Jakarta: Salemba Empat.

Al-Faizin, Abdul Wahid dan Akbar, Nashr. 2010. Tafsir Ekonomi Kontemporer : Kajian Tafsir Al-Quran Tentang Ekonomi Islam. Jakarta: Madani Publishing House.

Anoraga, Pandji dan Pakarti, Piji. 2006. Pengantar Pasar Modal. Edisi Revisi, Cetakan Kelima. Jakarta: PT Rineka Cipta

Arifin, Ali. 2004. Membaca Saham. Edisi Kedua. Yogyakarta: ANDI

Ayub, Muhammad. 2007. Understanding Islamic Finance. England: John Wiley \& Sons Ltd

Bajkowski, J. (1999, 4). Financial Statement Analysis : A Look At The Income Sheet. AAII Journal, 23 - 26

Bajkowski, J. (1999, 8). Financial Ratio Analysis : Putting The Numbers To Work. AAII Journal, 3 - 7

Buku Panduan Indeks Harga Saham Bursa Efek Indonesia Tahun 2010

Bungin, Burhan. 2005. Metodologi Penelitian Kuantitatif: Komunikasi, Ekonomi, dan Kebijakan Publik Serta Ilmu-ilmu Sosial Lainnya. Edisi Pertama, Cetakan Kedua. Jakarta: Kencana

Darmadji, Tjiptono dan M. Fakhruddin, Hendy. 2006. Pasar Modal di Indonesia: Pendekatan Tanya Jawab. Edisi Kedua. Jakarta Salemba Empat

Deitiana, Tita. (2011,4). Pengaruh Rasio Keuangan, Pertumbuhan Penjualan, dan Dividen Terhadap Harga Saham. Jurnal Bisnis dan Akuntansi, Vol. 13, No. 1, $57-66$

Djarwanto. 2004. Pokok-pokok Analisa Laporan Keuangan. Edisi Kedua, Cetakan Pertama. Yogyakarta: BPFE Yogyakarta

Fama, E. F. $(1965,1)$. The Behavior of Stock Market Prices. The Journal of Business, Vol. 38, No. 1, $34-105$

Fatwa Dewan Syariah Nasional-Majelis Ulama Indonesia (DSN-MUI)

Gujarati, Damodar N. 2011. Dasar-Dasar Ekonometrika (Buku 2, edisi ke-5). Jakarta: Salemba Empat.

Hadianto, B., \& Setiawan, R. (2007, 11). Pengaruh Volume Perdagangan, EPS, dan PER Terhadap Harga Saham Sektor Pertambangan Pada Periode 2000 2005 di Bursa Efek Jakarta. Jurnal Manajemen, Vol. 7, No. 1, 81 - 96

Hanafi, Mamduh M. dan Halim, Abdul. 2005. Analisa Laporan Keuangan. Edisi Kedua, Cetakan Pertama. Yogyakarta: UPP AMP YKPN

Harahap, Sofyan Syafri. 2002. Teori Akuntansi Laporan Keuangan. Edisi Pertama, Cetakan Ketiga. Jakarta: Bumi Aksara 
Haryanto, \& Sugiharto, T. (2003). Pengaruh Rasio Profitabilitas Terhadap Harga Saham Pada Perusahaan Industri Minuman di Bursa Efek Jakarta. Jurnal Ekonomi dan Bisnis, Vol. 8, No. 3, 141 - 152

Hin, L. Thian. 2008. Panduan Berinvestasi Saham. Edisi Terkini. Jakarta: PT Elex Media Komputindo

Husnan, Suad. 2001. Dasar-dasar Teori Portofolio dan Analisis Sekuritas. Yogyakarta: AMP YKPN

I.D., A., \& Olowookere, J. K. $(2011,4)$. The Contributions of Capital Market To Economic Development In Nigeria. International Journal of Economic Development Research and Investment, Vol. 2, No. 1, 36 - 46

Iqbal, Zamir dan Mirakhor, Abbas. 2008. Pengantar Keuangan Islam: Teori dan Praktik. Cetakan Pertama. Jakarta: Kencana Prenada Media Group

Jogiyanto, H.M. 2000. Teori Portofolio dan Analisis Investasi. Yogyakarta: BPFE Yogyakarta

Kamaruddin, Ahmad. 2004. Dasar-dasar Manajemen Investasi dan Portofolio. Jakarta: Rineka Cipta

Khusna, F.K. 2009. Analisis Pengaruh Variabel Fundamental Terhadap Harga Saham Perusahaan Pertambangan (Studi Pada Bursa Efek Indonesia). Skripsi Sarjana pada FE UIN Maulana Malik Ibrahim Malang: tidak diterbitkan

Laporan Tahunan Perusahaan Periode 2008 - 2012

Mar'ati, F. S. (2010, 7). Mengenal Pasar Modal (Instrumen Pokok dan Go Public). Among Makarti, Vol. 3, No. 5, 79 - 88

Metwally. 1995. Teori dan Praktek Ekonomi Islam. Jakarta: Bangkit daya Insani

Nachrowi, D Nachrowi dan Hardius Usman. 2006. Pendekatan Populer dan Praktis Ekonometrika Untuk Analisis Ekonomi dan Keuangan. Jakarta: LP FE Universitas Indonesia

Nugroho, W. (2009, 12). Analisis Pengaruh Pengembalian Investasi dan Penerimaan Per Saham Terhadap Harga Saham (Studi Pada Perusahaan Rokok di Bursa Efek Indonesia). Jurnal Ekonomi Bisnis, Vol. 14, No. 3, 208 $-214$

Pasaribu, R.B.F. $(2008,7)$. Pengaruh Variabel Fundamental Terhadap Harga Saham Perusahaan Go Public di BEI. Jurnal Ekonomi dan Bisnis. Vol. 2, No. $2,101-113$

Permana, Y., \& Sularto, L. (2008,8). Analisis Pengaruh Fundamental Keuangan, Tingkat Bunga SBI, dan Tingkat Inflasi Terhadap Pergerakan Harga Saham. Jurnal Ekonomi Bisnis, Vol. 13, No. 2, 103 - 111

Rahardjo, Budi. 2005. Laporan Keuangan Perusahaan: Membaca, Memahami, dan Menganalisis. Cetakan Kedua. Yogyakarta: Gadjah Mada University Press 
Analisis pengaruh Return On Asset (ROA), Return On Equity (ROE), Earning... Journal of Enterprise and Development (JED), Vol. 1, No. 2, December 2019

Sartono, Agus. 2001. Manajemen Keuangan Teori dan Aplikasi. Yogyakarta: BPFE Yogyakarta.

Sitompul, Asril. 2004. Pasar Modal: Penawaran Umum dan Permasalahannya. Edisi Revisi, Cetakan Ketiga. Bandung: PT Citra Aditya Bhakti.

Sussanto, H., \& Nurliana, D. $(2009,4)$. Analisis Pengaruh Fundamental dan Risiko Sistemik Terhadap Harga Saham Pada Perusahaan Perdagangan di BEI. Jurnal Ekonomi Bisnis, Vol. 14, No. 1, 19 -27

Taj El-Din, S. (1985). Towards an Islamic Model of Stock Market. Journal of King Abdul Aziz University: Islamic Economics, Vol. 3, No. 1, 57 - 81

Tandelilin, Eduardus. 2001. Analisis Investasi dan Manajemen Portofolio. Yogyakarta: BPFE Yogyakarta

Tandelilin, Eduardus. 2010. Portofolio dan Investasi: Teori dan Aplikasi. Yogyakarta: Kanisius

Undang-Undang No. 8 Tahun 1995 tentang Pasar Modal (UUPM)

Untung, Hendrik Budi. 2011. Hukum Bisnis Pasar Modal. Yogyakarta: Penerbit ANDI.

Widarjono, Agus. 2007. Ekonometrika Teori dan Aplikasi Untuk Ekonomi dan Bisnis. Yogyakarta: Ekonisia.

Widyatmini, \& Damanik, M.V. $(2009,4)$. Pengaruh Pertambahan Nilai Ekonomis dan Analisis Fundamental Terhadap Harga Saham (Studi Pada Sektor Industri Perdagangan Retail). Jurnal Ekonomi Bisnis, Vol. 14, No. 1, 39 - 50

www.finance.yahoo.com

Zuliarni, Sri. (2012, 10). Pengaruh Kinerja Keuangan Terhadap Harga Saham Pada Perusahaan Mining And Mining Service Di Bursa Efek Indonesia (BEI). Jurnal Aplikasi Bisnis. Vol. 3, No. 1, 36 - 48 